Postprint version of: "Pattern borrowing and hybridization in Mubi (East Chadic): The importance of congruence”. Word Structure 14:2, 2021, pp. 246-270. doi:10.3366/word.2021.0189

\title{
Pattern borrowing and hybridization in Mubi (East Chadic): The importance of congruence
}

\author{
Lameen Souag \\ LACITO - CNRS / Université Sorbonne Nouvelle / INALCO
}

\begin{abstract}
The plural system of Mubi (East Chadic, Afroasiatic) stands out cross-linguistically within Chadic and worldwide for its extensive use of pattern morphology, fixing the output's vowel qualities and shape while preserving the input's consonants. This paper demonstrates that, while some elements of this system may be conserved from earlier stages of Afroasiatic, others reflect the influence of Chadian Arabic, the regional lingua franca. The process of influence, however, turns out to involve not just straightforward pattern morpheme borrowing (exemplified here by the iambic pattern $\mathrm{BaCa} \mathrm{CDiFe}$ ), but also the reshaping of inherited patterns. The most frequent quadriliteral plural pattern, $B u C o o D u F$, reflects Arabic influence in its shape - mediated by a change in mapping directionality - but Chadic inheritance in its distribution. This result supports the hypothesis that pattern morphology is more easily transferred between related languages.
\end{abstract}

\section{Introduction}

A typologically unique morphological feature of Afroasiatic (Arcodia 2013) is the pervasive use of 'patterns' -- templates that fix vowel qualities and shape in the output while largely ignoring those of the input. This phenomenon is both strongly genetic and strongly areal: almost all languages using pattern morphology are not only related to but also in contact with other pattern-using languages. Such contact has been argued to promote the retention of inherited patterns (Vanhove 2012; 2020), but in some cases its effects go rather further: like other morphological relations, such patterns can be borrowed across languages (Arnold 2007; Bulakh \& Kogan 2011; Coghill 2015). The study of the conditions governing their borrowing, however, is still in its infancy, and the very existence of this type of borrowing is usually ignored by general studies of language contact, as in Matras (2009); it has been analysed as combining matter and pattern borrowing (Gardani 2020). Most of the few examples explicitly addressed in the literature relate to contact between closely related Semitic languages, limiting their generality; a recent exception is Souag (2020).

Mubi, an Afroasiatic language of central Chad, is one of the relatively few Chadic languages to make extensive use of transfixational pattern morphology (Jungraithmayr 2013). This has been interpreted as a common Afroasiatic inheritance reflecting a degree of conservatism unusual within Chadic (Jungraithmayr 2018). However, over the past millennium Mubi has also been strongly influenced by a non-Chadic root-and-pattern language: Arabic. The role of contact in the expansion of Mubi pattern morphology has not yet been explored in the literature. In the light of comparative evidence, one set of plural patterns stands out as particularly likely to reflect Arabic influence: quadriliteral patterns with a long non-high vowel infixed, BuCooDuF/BiCeeDiF / BaCaaDiF. This paper will examine the evidence, ultimately concluding that both Arabic influence and Chadic 
inheritance have played a role in the emergence of these plural patterns. The results confirm that contact between related languages has helped to reinforce transfixational pattern morphology not only within Semitic but also between different branches of Afroasiatic.

\subsection{Notation}

Prototypically, affixal morphology concatenates phonological material to the stem or root without changing the stem's phonological content; such morphology is easily represented as a string with a dash indicating its position relative to the stem (e.g. $-s$ for the common English plural). Pattern morphology, on the other hand, preserves some elements of the stem or root - usually, the consonants and their order - while overwriting others - notably, the vowels and the syllabic structure. For example, the Arabic plural of film is ?aflaam. A speaker hearing this plural and unfamiliar with the singular can easily reconstruct the singular's consonants $f-l-m$, but can only guess at the position and quality of its vowels: contrast, with the same plural pattern, šaxs

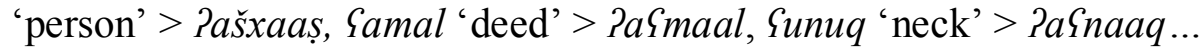

To represent pattern morphology, it is thus necessary not only to transcribe the vowels and invariant consonants of the pattern, but also to indicate the positions where stem consonants will appear. For convenience, patterns will be represented here as ordered strings, using the notation $B, C, D, F \ldots$ to represent the consonants of the singular, in that order, $V$ to represent unspecified vowels, and $v$ to represent otherwise unspecified high vowels; this is not intended to presuppose any particular analysis of the phenomenon. The Arabic plural type exemplified by Paflaam, for instance, will thus be represented as ?aBCaaD. Geminate consonants are treated for this purpose like clusters of two identical consonants, as exemplified in 4.1-2.

\subsection{Methodology}

To determine what role Arabic influence did or did not play in the emergence of the Mubi plural patterns $\mathrm{BuCooDuF} / \mathrm{BiCeeDiF} / \mathrm{BaCaaDiF}$, we need a way to look at its history. In the absence of any written material for Mubi prior to the 19th century, this will require the usual tools of historical linguistics: in particular, internal analysis, and the comparative method. For internal analysis, the basic insight of structuralism is sufficient for present purposes: that elements in complementary distribution, whether phonological or morphological, are to be analysed as contextually specified realizations of a single underlying element (Swadesh 1934; Harris 1942), whereas ones in contrastive distribution are distinct. The other main tool requires more attention.

The comparative method rests upon the discovery of regular correspondences between different languages. Typically, these correspondences are phonological; for instance, English /t-/ corresponds regularly to German /ts-/ (orthographic $<\mathrm{z}>$ ), as illustrated by ten - Zehn, tooth - Zahn, two - zwei, etc. What makes a correspondence regular - or, strictly speaking, recurrent - is its lexical distribution: a regular correspondence is one that is attested across a wide range of pairs of words whose meanings are sufficiently similar and whose other elements also participate in regular correspondences. In contexts where morphology is lexically specific, the same procedure can be applied with morphemes (Ratcliffe 1998: 15): thus French gentilic $/-\varepsilon /<$-ais $>$ corresponds to Italian /-eze/ <-ese>, as illustrated by français - francese 'French', lyonnais - lionese 'Lyonnais', calabrais - calabrese 'Calabrian', etc, in a lexically specific complementary distribution with seemingly comparable gentilics such as italien - italiano 'Italian', parisien - parigino 'Parisian', etc. If, across a pair of languages, two morphemes expressing the same function show closely similar distributions across cognate words, they should be analysed as corresponding regularly.

However, the identification of such regular correspondences is complicated by the semantic interpretability of morphemes, which may lead to changes in class membership (Koch 2015: 303). 
Morphemes can become more productive and be extended to apply to words that they formerly could not apply to (e.g. English $-s$ being extended to brothers, replacing brethren), or conversely be reduced to a few relict irregular cases by the extension of other morphemes expressing the same function (e.g. English -en, marginally surviving on words like oxen but formerly much more widely used). Irregular forms must thus be given particular weight in morphological comparisons.

Just as regularly corresponding sounds require the linguist to postulate a proto-sound from which they derive, so regularly corresponding morphemes require the postulation of a proto-morpheme. When the correspondence is both morphologically and phonologically regular, this is trivial. However, it is possible for a morphological regular correspondence to involve two morphs that do not regularly correspond to each other phonologically. Where a borrowed morpheme replaces an inherited one, such an outcome is to be expected; instead of the regular correspondences for cognates, such forms will normally manifest a different set of regular correspondences characteristic of the appropriate loanword stratum. Otherwise, an explanation other than straightforward regular transmission must be sought: irregular sound change (relatively common for high-frequency morphemes), or analogical interference from another morpheme (within the same language or in another one).

Transfixational patterns, of course, do not correspond very well to the prototypical item-andarrangement concept of a morpheme as a segmentable string of phonemes; they fit more intuitively into an item-and-process model (Hockett 1954). The process of morphological comparison, however, remains the same whether the pattern is analysed as an operation of association (McCarthy \& Prince 1990) or a morpheme (Bye \& Svenonius 2012), since the comparison depends only on the lexical distribution of the morphology being compared. To give a concrete example: just as French <-ais $>$ corresponds to Italian <-ese $>$, Standard Arabic plural $B a C a a D i^{n}$ corresponds to (Dellys) Algerian Arabic $B C a D a$ (Souag 2002), as shown not by the phonological correspondence (which in this case is partly irregular, probably by analogy with the quadriliteral plural template $B a C a a D i F-a h>B C a D F a$ - the expected regular reflex would have been $* B C a D i$ ) but by the shared distribution: zaraabi ${ }^{n}-z r a b a$ 'carpets', karaasi ${ }^{n}-k^{w} r a s a$ 'chairs', etc.

\subsection{Roadmap}

To establish the role of contact with Arabic in the development of Mubi quadriliteral iambic plurals, a number of stages are necessary.

Section 2 details background knowledge essential for the argument. Mubi's sociolinguistic situation in contact with Chadian Arabic (section 2) makes contact a prima facie plausible explanation for changes there. Knowing its position within the subgrouping of East Chadic (section 2.1) makes it possible to distinguish Mubi-specific innovations from older East Chadic features by examining their cross-linguistic distribution within the family. The rightward spread of rounding and frontness from high vowels in Mubi, along with comparative evidence from its closest relatives, allows the middle vowels of $B u C o o D u F / B i C e e D i F$ to be derived from $a a$ (section 2.2), and the rounding of $B u C o o D u F$ to be explained through a former plural suffix $-u(2.3)$.

The next two sections examine the history of Mubi quadriliteral iambic plural patterns using a comparative approach, building up the evidence necessary to make a contact scenario plausible. $B u C o o D u F$ and marginal BiCeeDiF (3) are evidently older within the language; they occur mainly with words of Chadic or non-Arabic origin (section 3.1), contrasting lexically with other plural patterns available for the same words (section 3.2). These words' cognates in other East Chadic B languages generally take * $B V C D a a F$ plurals; while the morphological correspondence is undeniable, the phonological correspondence is irregular, raising suspicions of contact. $\mathrm{BaCa} \operatorname{Di}(i) F$, in contrast, violates normal Mubi phonotactics and occurs exclusively or almost 
exclusively with Arabic loans (section 4.1), an example of Parallel System Borrowing (Kossmann 2010) indicating close familiarity with Arabic morphology. The related pattern $\mathrm{BaCa}$ CiFe has even been extended to inherited vocabulary (section 4.2), proving that Mubi speakers were sufficiently familiar with even rare Arabic plural patterns to use them productively.

Section 5 synthesises the findings of sections 2-4 to determine the specific role of contact and the mechanism through which it took place. Mubi BuCooDuF (and BiCeeDiF) $<* B v C a a D v F-u$ is not a regular reflex of the pattern $* B V C D a a F$ reconstructed from morphologically corresponding forms in other East Chadic B languages; the position of the $a a$ agrees not with Chadic but with Arabic. Occasional instances of Arabic $B a C a a D i(i) F$ shifting to Mubi $B u C o o D u F$, probably in earlier borrowings, suggest that the two were initially identified as cross-linguistically equivalent for the purpose of borrowing (section 5.1). Such an identification would have promoted a convergence in form, which could be accomplished by a simple parametric mechanism: mapping direction. Comparing quadriliteral plurals to iambic plurals of other lengths reveals that Mubi, like Arabic, maps this plural pattern from left to right. The rest of East Chadic B maps their corresponding patterns from right to left, which seems to represent the proto-Chadic situation.

Mubi thus not only borrowed some Arabic plural patterns but changed the directionality of pattern mapping to make an inherited plural pattern more similar to Arabic, leveraging preexisting similarities probably inherited from proto-Afroasiatic. The wider implications of this morphological hybridisation are discussed in section 6 , supporting the hypothesis that pattern morphology is more easily transferred between related languages.

\section{Background}

Mubi is spoken in central Chad, in more than a hundred villages scattered across an area extending north and east from the town of Mangalmé (Guéra Prefecture). Its Glottocode identifier is $<$ mubi1246> (Hammarström, Forkel \& Haspelmath 2019). The dominant language of the region is Chadian Arabic, which is by far the most widely spoken second language among Mubi (Johnson \& Mbernodji 2006). Among the East Chadic languages to which it belongs, Mubi stands out for its massive use of apophony and morphological complexity. Unless otherwise specified, all Mubi data here is taken from the most important published source on the language, Jungraithmayr (2013), which may be consulted for further details; it may be hoped that future fieldwork will serve to expand the available data. Prickett (2012) focuses mainly on verb morphology, and as such was less relevant here.

Mubi is spoken in the very multilingual Guéra region, alongside languages from several different families; the main lingua franca, however, is Chadian Arabic. As already noted by Baldi and Jungraithmayr (2008), Mubi hosts a large number of loanwords from Chadian Arabic, a language for which relatively good lexicographical resources are available (Jullien de Pommerol 1999; RothLaly 1969). All Chadian Arabic forms in this paper are from one of these two sources unless otherwise specified. Arabic has been spoken in Chad for more than 600 years (Owens \& Hassan 2008), though its earliest contacts with Mubi-speaking areas are not well documented. Over the past century or more, bilingualism in Sudanese Arabic varieties has also been promoted by Mubi emigration to Sudan (Alio 2008). After Arabic and the partly mutually intelligible Mubic languages Zerenkel and Masmaje, the next most widely understood language among Mubi speakers interviewed by Johnson and Mbernodji (2006) was the neighbouring Central Sudanic language Naba (specifically, the Bilala and Kuka varieties). Other neighbouring non-Chadic languages include Karanga (Maban) to the east and Daju (Eastern Sudanic) to the west (Lovestrand 2012a: 5); Daju also borders on Mubi's relatives Masmaje, Migama, and Bidiya, and has exerted an important influence on the latter (Alio \& Jungraithmayr 1989). 
In Mubi, noun plurals are frequently formed using stem-internal vowel changes, often combining with other strategies such as suffixation and partial reduplication. The range of vowel melodies involved in plural formation has been analysed by Jungraithmayr (1978; 2013), while Newman's (1990) general study of plurality across Chadic provides invaluable broader comparative context. However, present purposes make it necessary to delve further into the details of plural formation in Mubi and its nearest relatives than these sources. To understand the system language-internally, it is necessary not just to look at the range of vowel melodies used but to consider to what extent a given plural pattern (template) can be predicted from the form of the singular. To place it in historicalcomparative perspective, and thus understand its diachronic development, it is necessary not only to examine the use of individual formatives like $a$-infixation, but - along the lines of Ratcliffe (1998) - to compare the lexical distribution of specific plural patterns across cognate nouns. Any resulting errors in analysis are the author's responsibility.

The focus here will be on the history of quadriliteral patterns with a long non-high vowel infixed: $B u C o o D u F / B i C e e D i F / B a C a a D i F$. In a comparative Afroasiatic perspective, such patterns immediately recall Arabic $\mathrm{BaCaaDi}(i) F$ and its equivalents in languages of Ethiopia/Eritrea and South Arabia. Yet, as argued by Ratcliffe (1998: 211, 234), the limited distribution of this plural within Semitic suggests an innovation diffusing from somewhere in Arabia (most likely areally through intra-Semitic contact, contra Ratcliffe) rather than an inheritance from Proto-Semitic, much less from Proto-Afroasiatic. In the context of Mubi's close contact with Arabic, this suggests borrowing; yet, for $\mathrm{BuCooDuF} / \mathrm{BiCeeDiF}$, the evidence of lexical distribution suggests otherwise. To resolve the apparent paradox, comparative East Chadic data will prove indispensable.

Before proposing any historical analysis of Mubi's quadriliteral plural system, however, two preliminary points will require attention: the phylogenetic classification of Mubi, and relevant aspects of its phonology.

\subsection{Classification}

The available linguistic data on Mubi is too recent to permit its history to be written based on direct observation; to understand the development of a given feature, it is necessary to examine its cognates in related languages. For this purpose, an understanding of the relevant phylogeny is indispensable. Mubi belongs to the eastern subgroup of East Chadic (East Chadic B), a subgroup first proposed by Newman (1977), and thus ultimately to the Afroasiatic phylum (Greenberg 1963). As such, it is extremely distantly related to Arabic, which belongs to the Semitic branch of Afroasiatic. The two most recent subclassifications of East Chadic B are Lovestrand (2012a), based essentially on lexicostatistics but with comprehensive coverage, and Peust (2018), based on shared innovations and therefore examining only those languages for which relatively good data is available. In this paper, I will assume Peust's more extensively argued tree structure, but add languages not examined by Peust (between square brackets) in the position where Lovestrand's lexicostatistics would suggest they should be placed. I also give the subgroups names for convenience.

Mubic: Kajakse, [Masmaje], Mubi, [Zerenkel]

Guera proper:

Northern Guera:

Danglaic: Migama; Dangaleat, Bidiya

[Mabire]

[Jonkor]

Birgitic: [Mogum, Toram], Birgit

Southern Guera (=B.3-4):

Sokoroic (B.3): Ubi; [Mawa]; [Saba, Tamki]; Sokoro 


\section{Barain (=B.4)}

For several of these languages, only minimal data has been published. The languages that principally concern us here are those for which relatively extensive lexical and grammatical data on plurals is available, marked by bold italics. Dedicated lexical monographs including sketch grammars were available for Mubi (Jungraithmayr 2013), Migama (Jungraithmayr \& Adams 1992), Bidiya (Alio \& Jungraithmayr 1989), and Dangaleat (Fédry 1971). Article-length sketches were available for Birgit (Jungraithmayr 2004) and Mogum (Jungraithmayr 1961), and wordlists including some plurals and brief analysis for Kajakse, Masmaje, Toram, and Ubi (Alio 2004).

As far as can be determined from available materials, the Southern Guera languages have preserved few traces of any kind of internal plural marking, resorting almost exclusively to suffixation with only sporadic traces of vowel raising or lengthening - Ubi -reetì, Barain -yá, Saba - $\varnothing /-\eta$, etc. (Lovestrand 2012b: 73; de Rendinger 1949). Comparative data below will therefore draw primarily upon Mubic and Northern Guera, with occasional comparisons further afield to (East Chadic A) Tumak (Caprile 1975) and to (West Chadic) Hausa (Newman 2007; Bargery 1934).

Given the tree structure proposed by Peust, any feature with cognates in both Mubic and Northern Guera should in principle be reconstructed for proto-East Chadic B. However, contact between the two groups cannot be neglected as a possible explanation; Mubic languages border on Danglaic and on Birgit (Northern Guera). Innovations shared between Mubic and Mogum or Toram, which do not border on each other, should thus be given extra weight. The diversity of Chadic often makes it difficult to find convincing cognates further afield, but to the extent that they can be found in other branches, they further strengthen the evidence for antiquity. Extra-Chadic contact must, of course, also be taken into consideration; Mubic and Northern Guera are both in contact with both Arabic and Daju (Eastern Sudanic), and shared items are sometimes common loans.

\subsection{Phonology}

A few points in Mubi phonology need to be covered before examining plural formation. First, a few points regarding the consonant system: final plosives are automatically devoiced $(b>p, d / d>$ $t, j / f>c, g>k$ ), and, for the purposes of pattern/template imposition, all words transcribed as vowel-initial are to be treated as having an untranscribed word-initial first consonant (either $\mathrm{B}=/ \mathrm{R} /$ or $\mathrm{B}=\varnothing$, depending on whether one follows Jungraithmayr's analysis or Prickett's). Second, high vowels spread features to their left, meaning in particular that ee and oo often reflect underlying or historic /aa/.

In the context of verb morphology, Frajzyngier (1981) has argued for a rule raising vowels before $i$ in Mubi, but for some reason specifically excludes $a$ from being affected by this rule. The exclusion is not necessary; Mubi shows clear evidence for a raising of $a$ to $e$ before $i$ (and, in one context, $u$ ):

$$
\mathrm{a} \rightarrow \mathrm{e} / \ldots[+ \text { high }]
$$

Morphophonologically, this process remains active. As Jungraithmayr $(2013: 44,47)$ establishes, verbs with the vowel pattern $a-a / i$-aa or $o$ become respectively $a-i / i$-ee or $u$ if a suffix pronoun containing $i / u$ is added. Similarly, the adjectival suffix -it changes $a(a)$ to $e(e)$ in the stem to which it is added (Jungraithmayr 2013:37), and, with monosyllabic nouns, possessive suffixes with $i$ as their only vowel change $a$ to $e$ (Jungraithmayr 2013: 59-61). Comparable cases involving gender suffixes can also be found in the lexicon, e.g. mísáanō (m.) vs. miséen̄i (f.) 'red ant'.

Diachronically, comparison to Mubi's nearest relatives yields cases such as: 


$\begin{array}{lll}\text { (2) 'fire': } & \text { Kajakse kàwi } & \text { vs. Mubi kèwwí } \\ \text { 'hot': } & \text { Kajakse kàri } & \text { vs. Mubi kèrî } \\ \text { 'goat': } & \text { Kajakse wàagirì } & \text { vs. Mubi wèegírì } \\ \text { 'garment': } & \text { Kajakse bàatike } & \text { vs. Mubi bèedígi }\end{array}$

Mubi also reflects a process of rounding spread: word-internally, $u$ rounds the vowel of a preceding syllable, irrespective of height. This does not seem to be actively evidenced in the morphophonology, but is supported by some Mubic comparisons:
(3) 'lance':
Kajakse caabúk
vs. Mubi cóbbi
'mouse/rat'
Kajakse gàmburò
vs. Mubi gómbórō

The lexicon, excluding Arabic loanwords, is almost entirely consistent with this rule. There are no non-Arabic cases of $a a . . . u$; no cases with $e e . . . u$ apart from one minor plural pattern (kídéesú 'pestles', rìdéedù 'goldenrain trees', silléedù 'acacias'); and only two cases with $i . . . u$ (lìssù 'Daju (pl.)', síisùwá 'star').

The following rules thus seem to have been operative at some stage of the language, with the former at least still remaining morphophonologically productive:

$$
\begin{aligned}
& \left.\mathrm{a} \rightarrow \mathrm{e} /{ }^{[+ \text {high }}\right] \\
& {[- \text { round }] \rightarrow[+ \text { round }] / \_\mathrm{u}}
\end{aligned}
$$

\section{3 $-u$ as a Mubic plural suffix}

A number of relict plurals in Mubi can be analysed as preserving a plural suffix $-u$ forming a paradigm with the attested singular gender suffixes masculine $-o$ and feminine $-e$ (in no cases does it seem to correspond to feminine $-i$ ):
'blind':
fùbáàg-ò m., fùbáàg-è f., fùbòog-ú pl.
'lazy':
mársíy-ò m., mársìy-è f., mòrs-ù pl.
'Arab (Shuwa)': sùwàng-ót m., sùwàng-ét f., sùwòong-ú $\mathrm{pl}$.
'cat':
sìnàar-ó $\mathrm{m} .$, sìnòor-ú $\mathrm{pl}$.
'wildcat':
gàayìm-ó m., gòoyùm-ú pl. (or gùyòomú)
'squirrel':
sògòryàk $\mathrm{m}$., sògòryùg-ú $\mathrm{pl}$.

Kajakse provides further support for a $-u$ plural suffix:

(7) 'horse': fárs-ò sg., fars-u pl. (Mubi: firs-ō m., firs-í f., firá(a)s pl.)

'skin': tàw-ò sg., tàw-ù pl. (Mubi: tòg-ò m., tùgók pl.)

'sheep': tùmàa?-i f., tùmàa?-u pl. (Mubi: támák m., túmák f., túmóok pl.)

A third Mubic language, the poorly documented Masmaje, provides examples of this suffix being added to an internal plural. In both examples the plural could potentially be a borrowing from some variety of Arabic; internal-aa plurals ?afraas and Pasyaaf were available for these words in Classical Arabic, though for Chadian Arabic Jullien de Pommerol (1999) rather gives the plurals fursaan and suyuuf (both also found in Classical Arabic). For present purposes, the ultimate source of the internal plural of these words matters less than the fact that it was combined with $-u$. 
(8) 'horse': fárs-ò sg., firaas-ù pl. (Classical and Chadian Arabic faras)

'lance': fèysìn-e sg., fiyàasùn-u pl. (no clear cognates observed in other East Chadic B languages; likely borrowed via Daju from some dialectal reflex of Classical Arabic sayf / Chadian Arabic seef 'sword', with metathesis and the addition of the Daju sg. suffix -ne.)

As will be seen below, the external correspondences of several Mubi plural types are easier to explain on the assumption that a suffix $-u$ has been absorbed into the stem, inducing a shift $a a>o o$. The exact conditions of this final vowel deletion need further investigation, but are potentially related to pre-Mubi stress position, with vowel deletion after accent in final open syllables, as argued for the verbal system by Wolff (1988: 169).

\title{
3 Phonologically regular quadriliteral plurals
}

As outlined in the introduction, three Mubi quadriliteral plural patterns stand out as particularly likely to reflect Arabic influence: $\mathrm{BuCooDuF} / \mathrm{BiCeeDiF} / \mathrm{BaCaaDiF}$. Despite sharing a long medial vowel originally deriving from *aa, however, these three differ in one important respect. As seen in section 2.2 above, Mubi spreads frontness and roundness leftwards from high vowels. As a result, it does not normally allow the sequence $a a . . . i$ in inherited vocabulary. Most quadriliteral nouns - including almost all non-Arabic ones - take plural patterns conforming to this constraint. This suggests that $B u C o o D u F$ and $B i C e e D i F$ are older within Mubi than BaCaaDiF. Before attempting to determine to what extent Arabic played a role in the development of these plural patterns, it is necessary to reconstruct their history by placing them in the wider context of quadriliteral plurals within Mubi (in section 3.2) and across its nearest relatives (in section 3.3).

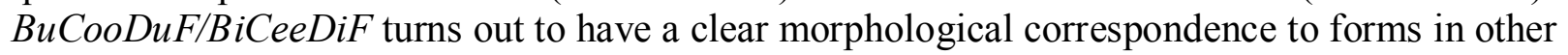
East Chadic languages, making an explanation in terms of contact alone untenable. Yet the phonological correspondence between the Mubi form and the morphologically corresponding forms elsewhere is unexpectedly irregular in a manner that cannot convincingly be explained familyinternally, suggesting a potential role for contact.

\subsection{BvCVVDvF plurals and related forms}

\subsubsection{BuCooDuF plurals}

In Mubi, four-consonant nouns $B V C(V)(V) D V F(V)$ most often (17 examples) form a plural of the pattern $B u C o o D u F$; if a consonant cluster is present between the first two syllables, it is broken up. Only one example has a final $-i$. The second and final consonants are almost always sonorants $(m, n, l, r)$.

\author{
kálmàn 'in-law' > kúlóomùn \\ kílkílā 'millstone roughener' > kúlóokúl \\ jòlkòm 'chin' > jùlóokúm \\ fórfórō 'honeycomb' > füróofúr \\ gòngòl 'axe' > gùnòogùl \\ kórkór(o) 'hive'> kúróokúr \\ tòmtòm 'acacia sp.' > tùmóotúm \\ dòngòrè 'dull' > dùnóogùr \\ dúrgúl 'donkey' > dúróogúl \\ kúllùk 'ostrich' > kúlóodùk \\ kŭrkúr 'puppy' (f. kiréekirè!) > kúróokúr
}


múlmúli 'calf (of leg)'> múlóomúl

(à)ngúmbùl 'calabash'> (à)ngùnóobùl

súnsúnà 'tale' > súnóosún

Examples without a $C D$ consonant cluster in the singular are rare, but attested:

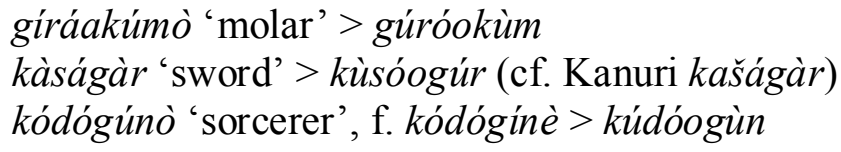

\subsection{2 ВuCoDFu plurals}

The plural pattern $B u C o D F u$ can be treated as a conditioned allomorph of $B u C o o D u F$, applying only to quadriliteral singulars with a consonant cluster after the first two syllables. The cluster is maintained at the expense of templatic vowel length, yielding singular $B V C V D F V(G)>$ plural $B u C o D F u$. Only two examples seem to be attested, both probably loanwords:

(11) gòmórk-ó 'basket' > gùmòrkú (found with the Daju -ne suffix in Bidiya gòmórkine) sùwàng-ót 'Arab (Shuwa)' > sùwòongú

A quintiliteral example is also found:

$$
\text { áránjál-à 'kidney' > ùrònjúl }
$$

\subsubsection{Irregular cases}

In one case, an -e is irregularly added to the usual template:

$$
\text { dòngùl 'bed' > dùnóogúlè (cf. Chadian Arabic darangal) }
$$

The only attested case with a semivowel cluster yields a slightly different and unique outcome, BuCDooFu:

$$
\text { gàywày 'elephant' > gùywòoyú }
$$

Two otherwise unremarkable nouns of this form take fronted BiCeeDiF instead of $B u C o o D u F$ :

$$
\text { mùrbòn-ót } \mathrm{m} \text {., mùrbòn-ét } \mathrm{f} \text {. 'Masmaje person' > miréebìn }
$$

dólgúm f. 'basket' > díléegìm

The alternative BiCDeeFuF plural for dingíri 'branch' > dángár / dingéerúr is sui generis, seeming to combine these two irregularities with subsequent final consonant reduplication, a process attested productively for biliteral plurals in Mubi (e.g. càáró 'root' > còorùr).

\subsection{Other quadriliteral plural types}

There are a total of 22 examples of $B v C V V D v F$ - plurals with frontness/roundness spreading. Confirming the need to lexically specify plural formations, these contrast with 14 recorded quadriliterals that do not take a plural of this kind (excluding the Arabic loans covered further on). One is suppletive: tángála 'bull' > tìráàn (plural < Arabic). Three, all with homorganic nasal $C$, use a similar template $B o(o) C D u F$, reminiscent of the better-attested triliteral template $B o o C u D$ : 
(16)

téngíl 'calf' > tóngúl
mínjílò 'Mubi person' > mónjúl
húmbúk 'hedgehog' > hòombúk

Four can be analysed as formed by removing a gender marker (some could also be examples of other plural types):

$$
\begin{aligned}
& \text { kàldày-ó 'toad sp.' > kàldày } \\
& \text { Bèrgòd-ót } \mathrm{m} ., \text { Bèrgèd-ét } \mathrm{f} \text {. 'Birgit person' > Bèrgèt } \\
& \text { mbùrtùt-ó 'toad sp.' > mbùrtùt } \\
& \text { tòngúr-ò 'little braid' > tòngùr / tàyáayirè }
\end{aligned}
$$

The remainder - including all but one of the quadriliterals nouns ending in $-i$ - involve patterns with a single short non-high vowel linked to two positions, $B a C D a F / B e C D e F / B o C D o F$, in one case with suffixed $-e$ :

$$
\begin{aligned}
& \text { dingírí 'branch' > dángár / dingéerúr } \\
& \text { mùndúrò 'boy', mindírè 'girl' > màndàr } \\
& \text { gómbórō 'rat sp.' > gàmbàrè } \\
& \text { tìngéedi 'ant' > tèngèt } \\
& \text { jùngúdòo 'clitoris' > jèngèt } \\
& \text { imbéèlì 'ember' > òmbòl }
\end{aligned}
$$

\begin{tabular}{|c|c|c|c|}
\hline & Mubi & Kajakse & Masmaje \\
\hline $\begin{array}{l}\text { donkey } \\
\text { pl. }\end{array}$ & $\begin{array}{l}\text { dúrgúl } \\
\text { dúróogúl }\end{array}$ & $\begin{array}{l}\text { dúrkùl } \\
\text { diràakìli }\end{array}$ & - \\
\hline $\begin{array}{l}\text { chin/jaw } \\
\text { pl. }\end{array}$ & $\begin{array}{l}\text { jòlkòm } \\
\text { jùlóokúm }\end{array}$ & $\begin{array}{l}\text { còlgòm } \\
\text { cùloogùm }\end{array}$ & - \\
\hline $\begin{array}{l}\text { lance } \\
\text { (Ar. sayf 'sword' + Daju -ne?) }\end{array}$ & - & - & $\begin{array}{l}\text { fèysine } \\
\text { fiyàasùnu }\end{array}$ \\
\hline
\end{tabular}

Contrasting cases like fórfórō $>$ fùróofúr with gómbórō > gàmbàrè, it appears clear that, while the result of applying a particular plural pattern to a noun is predictable, the choice of plural pattern is not entirely predictable from the singular noun alone, and must be considered as lexically determined. This fact makes it easier to apply the comparative method, as discussed in section 1.2.

\subsection{East Chadic comparisons for Mubi $B v C V V D v F$ - plurals}

Within the scattered evidence available for other Mubic languages, a couple of attestations seem to confirm that cognate forms are present in the rest of this subgroup too, as shown in Table 1 (although one ${ }^{1}$ is probably a borrowing from Arabic).

Table 1. Mubic quadriliteral long vowel plurals

\footnotetext{
${ }^{1}$ The temptation to compare jòlkòm ‘chin/jaw' to Maghrebi Arabic šlāġm 'moustache' must be resisted; the latter word does not seem to be attested in Chad, and, in East Chadic A, Tumak jìgว̀m 'jaw' suggests that this word has been in Chadic rather longer.
} 
In light of Kajakse dìràakil-i and Masmaje fiyàasùn-u, Mubi dúróogúl can be explained as *diraakil- $u$ with rounding spread and incorporation of the suffix into the final syllable (cf. Kajakse tùmàa?-u vs. Mubi túmóok 'sheep'). The original Mubic quadriliteral plural can tentatively be reconstructed as * $B v C a a D v F$.

Outside of Mubic, however, the East Chadic B situation is rather different, as seen in Table 2. Internal non-high plurals for quadriliterals are well-attested in Dangaleat, Mogum, and Toram, and at least once even in Bidiya; in Migama, vowel lowering probably represents a relic of such a plural (otherwise normally triggered by $a$-suffixation, cf. Jungraithmayr and Addams 1992: 25). But in all these cases, clusters are consistently preserved: rather than $a$-insertion, we find $a$-ablaut of the last syllable. As previously, the second and final consonants are almost always sonorants (here, usually $l$ or $m$.)

Table 2. Quadriliteral a-plurals across East Chadic B

\begin{tabular}{|c|c|c|c|c|c|c|c|}
\hline & Kajakse & Mubi & Migama & Dangaleat & Bidiya & Mogum & Toram \\
\hline $\begin{array}{l}\text { donkey } \\
\text { pl. }\end{array}$ & $\begin{array}{l}\text { dúrkùl } \\
\text { dìràakili }\end{array}$ & $\begin{array}{l}\text { dúrgúl } \\
\text { dúróogúl }\end{array}$ & $\begin{array}{l}\text { dürkúl } \\
\text { dòrkòllì }\end{array}$ & $\begin{array}{l}\text { dürkùl } \\
\text { dúrkál }\end{array}$ & $\begin{array}{l}\text { durtíkilo } \\
\text { durtikili }\end{array}$ & $\begin{array}{l}\text { mirtélé } \\
\text { mirtal }\end{array}$ & $\begin{array}{l}\text { durkuk } \\
\text { dúrkàake }\end{array}$ \\
\hline $\begin{array}{l}\text { chin/jaw } \\
\text { pl. }\end{array}$ & $\begin{array}{l}\text { còlgòm } \\
\text { cùloogùm }\end{array}$ & $\begin{array}{l}\text { jòlkòm } \\
\text { jùlóokúm }\end{array}$ & - & $\begin{array}{l}\text { còlkùmò } \\
\text { côlkàm }\end{array}$ & $\begin{array}{l}\text { cogòlma } \\
\text { cogòlme }\end{array}$ & $\begin{array}{l}\text { colkom } \\
\text { colkam }\end{array}$ & - \\
\hline $\begin{array}{l}\text { bed piece } \\
\text { bed / pl. }\end{array}$ & - & $\begin{array}{l}\text { dòngùl } \\
\text { dùnóogúlè }\end{array}$ & - & $\begin{array}{l}\text { dáyílò } \\
\text { dáyàl }\end{array}$ & - & $\begin{array}{l}\text { dayalo } \\
\text { dayal }\end{array}$ & - \\
\hline $\begin{array}{l}\text { molar } \\
\text { pl. }\end{array}$ & - & $\begin{array}{l}\text { gíráakúmò } \\
\text { gúróokùm }\end{array}$ & $\begin{array}{l}\text { gàrgàmú } \\
\text { gàrgàmmá }\end{array}$ & - & $\begin{array}{l}\text { gòrgumà } \\
\text { gòrgumè }\end{array}$ & - & - \\
\hline $\begin{array}{l}\text { lion/monkey } \\
\text { pl. }\end{array}$ & - & - & - & - & - & $\begin{array}{l}\text { dúngùm } \\
\text { duygam }\end{array}$ & $\begin{array}{l}\text { dungum } \\
\text { dungàame }\end{array}$ \\
\hline $\begin{array}{l}\text { ant sp. } \\
\text { pl. }\end{array}$ & - & - & - & $\begin{array}{l}\text { tôntìl̀̀ } \\
\text { tôntàl }\end{array}$ & $\begin{array}{l}\text { tóntira } \\
\text { tóntiri }\end{array}$ & - & - \\
\hline $\begin{array}{l}\text { dirty water } \\
\text { pl. }\end{array}$ & - & - & - & $\begin{array}{l}\text { dúrpìnà } \\
\text { dûrpàn }\end{array}$ & - & - & - \\
\hline $\begin{array}{l}\text { bachelor } \\
\text { pl. }\end{array}$ & $\begin{array}{l}\text { marfa } \\
\text { màraafi }\end{array}$ & $\begin{array}{l}\text { márfá } \\
\text { míréèc }\end{array}$ & - & $\begin{array}{l}\text { mûrgìlè } \\
\text { múrgál }\end{array}$ & - & - & - \\
\hline $\begin{array}{l}\text { spring } \\
\text { pl. }\end{array}$ & - & - & - & - & $\begin{array}{l}\text { kùrbul } \\
\text { kùrbaalè }\end{array}$ & - & - \\
\hline $\begin{array}{l}\text { lizard } \\
\text { pl. }\end{array}$ & - & - & $\begin{array}{l}\text { bùrdùmá } \\
\text { bòrdòmmì }\end{array}$ & - & - & - & - \\
\hline
\end{tabular}

From Migama stem vowel lowering, Dangaleat and Mogum $B V C D a F$, and Bidiya and Toram $B V C D a a F-e$, we may reconstruct a quadriliteral plural $* B V_{l} C D V_{2} F(v)>* B V_{l} C D a a F$ for protoNorthern Guera. For proto-East Chadic B, comparing Mubic $* B v C a a D v F$, we may thus assume a quadriliteral plural with an - $a a$ - infix; but where was this infix positioned?

A couple of irregular Mubi forms tip the balance in favour of the last syllable. As seen above, gàywà 'elephant' takes the otherwise unattested plural gùywòoy-ú, retaining the $-u$ suffix, to be derived from *gvywaay- $u$ - an isolated example of $* B v C D a a F$ in Mubi. The singular is known to be reconstructible for proto-Chadic (Newman 1977), with cognates including Hausa giiwaa pl. giiwàayee - but is not attested in available Northern Guera data (where we instead find forms like Bidiya gárfà), making an intra-Chadic loan unlikely. The irregularity of this form within Mubi suggests an archaism rather than a recent formation. The even more irregular form dingiri 'branch' > dingéerúr, presumably to be derived from *dingaar-u plus final reduplication, further 
supports the reconstruction of $* B v C D a a F$ for pre-Mubi; its etymology is less clear, but cf. Dangaleat dêykiló 'stick'.

If pre-Mubi had $* B v C D a a F-u$, however, the irregular displacement of *aa from the final syllable to the middle remains to be explained. Comparison to Hausa suggests one potential explanation in terms of spread from reduplicated $B V C B V C(v)$ nouns, which account for 7 of the 22 examples

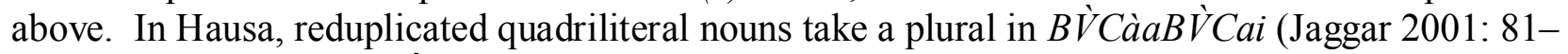
82), so we have kwiikwiyò 'puppy' > kwìyàakwìai like Mubi kŭrkúr 'puppy' > kúróokúr (cf. Bidiya kúrkid-o pl. $-i$ ). Allowing for the Hausa sound change of $* r>\mathrm{y}$ (Newman 1970), the two are plausibly cognate; the Hausa form can be derived regularly from pre-Hausa $* k^{w} i r k^{w} i r-o o>$ ${ }^{*} k^{w}$ ìràa $k^{w} i r-a i$. However, given the phylogenetic distance between Hausa and Mubi, and the fact that none of the other seven attested Mubi reduplicated nouns are known to have cognates with a comparable plural anywhere else in East Chadic B or in Hausa, this hypothesis is somewhat adventurous. Note that Newman (1990), based on a rather extensive survey of the family, does not reconstruct such a plural type for proto-Chadic, though he does separately reconstruct two of its components, internal $*_{-} a$ - and suffixed $*_{-}-a i$. Even if we were to use this single example to reconstruct a proto-Chadic plural pattern sg. ${ }^{*} B V C B V C(v)>$ pl. ${ }^{*} B V C a a B V C$-, surviving into East Chadic $\mathrm{B}$ alongside $* B v C D a a F$, the question remains of why the former should be generalized to non-reduplicated quadriliterals, which appear to be twice as frequent in the lexicon and to include more basic vocabulary ('in-law', 'donkey', 'chin'...) The examination of Arabic loanwords suggests a better explanation.

\section{Phonologically anomalous quadriliteral plurals}

As seen in the previous section, the quadriliteral plural patterns $B a C a a D i(i) F$ and $B a C a a D i F e$ stand out within Mubi for their anomalous phonotactics; the sequence $a a . . . i$ is normally excluded from inherited vocabulary. This fact is most easily explained by supposing them to be fairly recent loans postdating the change $\mathrm{a} \rightarrow \mathrm{e} / \ldots$ [ $[$ high] discussed in section 2.2 , and that hypothesis is amply corroborated by other evidence. Both patterns correspond perfectly to attested Arabic plural patterns, as laid out below, and the former at least is used overwhelmingly - perhaps exclusively with Arabic loans, as seen in section 4.1. Yet even these relatively recently borrowed plural patterns have spread to at least one inherited noun, as shown in section 4.2. This establishes that Mubi speakers were sufficiently familiar with Arabic plural morphology to use it productively, making it plausible in principle that Arabic could have affected the development of inherited plural morphology.

\subsection{BaCaaDi(i)F, BaCaaDo/u}

Chadian Arabic, like Arabic more generally, typically assigns quadriliteral nouns iambic plurals (McCarthy \& Prince 1990), of the form $B a C a a D i(i) F$. This was traditionally often analysed as two distinct plural patterns, $\mathrm{BaCaaDiF}$ and $\mathrm{BaCaaDiiF}$, but in both Classical and Chadian Arabic the two are in complementary distribution, with the length of the vowel in the plural's final syllable being determined by the length of the corresponding vowel in the singular; as such, they must be analysed as two allomorphs of one plural pattern, as done for instance by Zeltner and Tourneux (1986: 51). Thus for example in Chadian Arabic (Jullien de Pommerol 1999):

tangal 'hive' > tanaagil

fundug 'mortar' > fanaadig (cf. Classical Arabic funduq 'shop' > fanaadiq)

funjaal 'tea glass' > fanaajiil (cf. Classical Arabic finjaan > fanaajiin)

gadduum 'mouth (pej.)'> gadaadiim 
Across most varieties of Arabic including Chadian, this plural type is highly productive for nouns of the form $B v C D V(V) F$. Stress normally falls on the last heavy syllable (treating word-final consonants as extrasyllabic): thus $B a C a ́ a D i F$ but $B a C a a D i ́ i F$. A number of nouns of this type have been borrowed into Mubi along with their plurals. While some are adapted to Mubi morphology, in many cases they retain their Arabic plurals without even conforming to height spreading.

Jungraithmayr (2013) records a total of 14 plurals of the form $\mathrm{BaCaaDi}(i) F$, where all tones are low except on the vowel that would be stressed in Arabic: thus BàCáaDìF but BàCàaDíiF. E.g.:

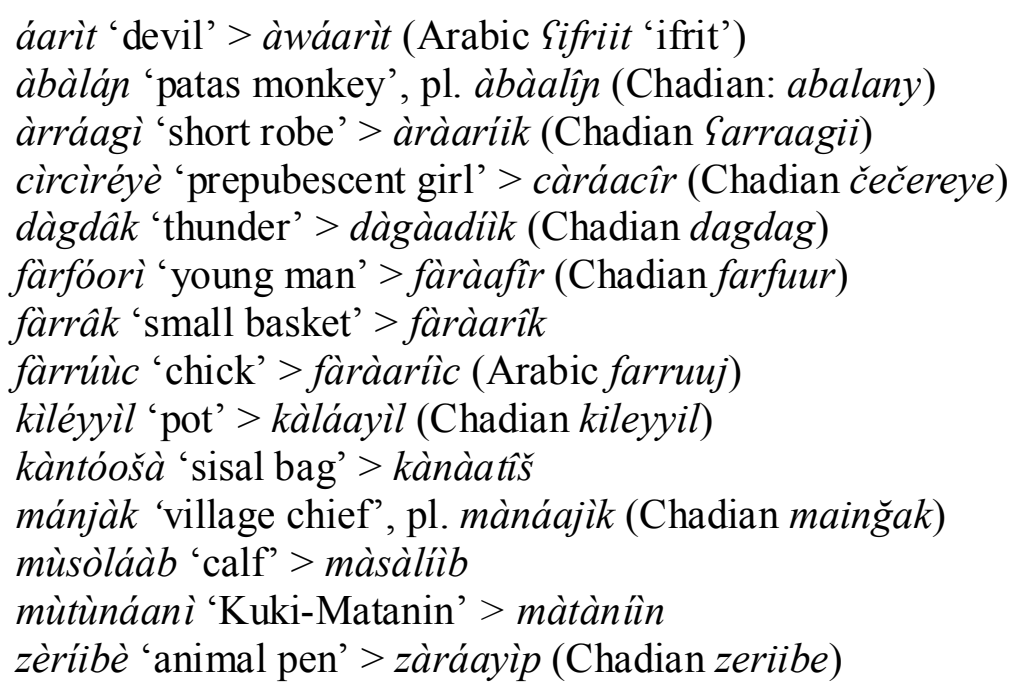

Another five are of the corresponding 'defective' form (analysable as an allomorph of the previous with a missing or semivocalic final consonant) as $\mathrm{BaCaaDo} / \mathrm{u}$ :

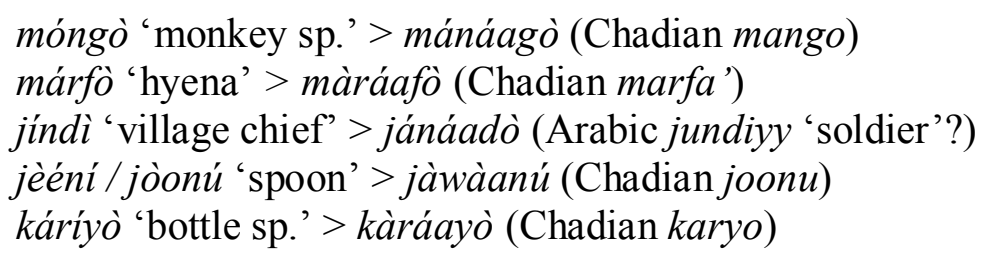

Of these, all but four - one an ethnonym - are known to have counterparts in Chadian Arabic , and sometimes in Arabic more generally. The rest look likely to be Arabic loanwords on the grounds of phonology ( $\check{s}$ is found only in Arabic loans) or shape. It thus seems clear that this plural type has been borrowed from Arabic. However, there is no evidence that it has been extended to inherited vocabulary.

\subsection{BaCaaDiFe}

Within Classical Arabic, BaCaaDi(i)F plurals alternate with a closely related form $B a C a a D i F-a h$, e.g. jabbaar 'mighty one' > jabaabirah, Sabqariyy 'genius' > Sabaaqirah. This pattern is rather less frequent than $\mathrm{BaCaaDi}(i) F$ (Ratcliffe 1998: 95) but productive especially for words of foreign origin (van Putten 2020: 66). In Mubi, we find only three examples of its expected reflex BàCáaDiFè (with the position of high tone corresponding once again to that of Arabic stress):

(22) Šàddáarì "shaman", pl. šàdáadìrè

érìn "scorpion", pl. àráarínè

tòngùrò 'little braid' > tòngùr / tàyáayírè 
Of these three, only šàddáarì 'shaman' (etymologically 'herbalist') is unambiguously of Arabic origin; it combines Chadian Arabic šadar < šajar 'tree, plant' with the BaCCaaDi agent noun template. Agent nouns of this form in Chadian Arabic typically take a plural $B a C C a a D a$, as rightly noted by an anonymous reviewer; $B a C a a D i F-e$ plurals do not appear to be well-documented in Chadian Arabic. Nevertheless, in light of the well-attested borrowing of $\mathrm{BaCaaDi}(i) \mathrm{F}$ and the failure of this template to exhibit $a \rightarrow e /$ borrowing as well.

$\mathrm{C} i$, this template must be interpreted as an Arabic

As such, it also provides the clearest available example in Mubi of an Arabic borrowed template being extended to inherited vocabulary. Mubi érìn 'scorpion' has no plausible Arabic source, and prima facie cognates are found throughout East Chadic B, reflecting something along the lines of *arin (see Table 3); yet the relationship between its singular and its plural has no attested parallel elsewhere in the family.

The Masmedje and Kajakse singulars slightly complicate the picture with their close resemblance to the Mubi plural. The Zerenkel form, with loss of the final nasal (whose former presence the Guera branch confirms), provides the missing link. In Mubi, biliterals often take plurals with reduplication of the last consonant (e.g. ndùuri 'shadow' > ndòoràr), with length on the second syllable when the first syllable of the singular is short (e.g. màbò 'old'> mùbóop from *mvbaab-u). While much less data is available for the rest of Mubic, plurals with final $-a(a) C$ reduplication are also attested for biliterals in Zerenkel (Souleyman, Abakar \& Ramat 2012): wíiri 'neck' > wíirárì; suwaawe 'calabashes' (sg. undocumented, but cf. Mubi sùwá pl. sùwów). We may thus suppose that truncated ari took a plural *araar, from which Kajakse and Masmeje back-formed a singular by adding the feminine suffix $-i$. Mubi speakers' contact with such forms in related languages might have helped encourage the rise of an Arabic-style plural àráarínè.

Table 3. 'Scorpion' in East Chadic B

\begin{tabular}{|c|c|c|}
\hline & Singular & Plural \\
\hline \multicolumn{3}{|l|}{ Mubic: } \\
\hline Mubi & érìn & àráarínè \\
\hline Zerenkel (Johnson 2005) & $\operatorname{ar} \bar{l}$ & $?$ \\
\hline Kajakse & Pàràar-i & Pàràar-àk \\
\hline $\begin{array}{l}\text { Masmedje (Marti, Mbernodji \& } \\
\text { Wolf 2007) }\end{array}$ & Péráríi & $?$ \\
\hline \multicolumn{3}{|l|}{ Guera proper: } \\
\hline \multicolumn{3}{|l|}{ Northern Guera: } \\
\hline \multicolumn{3}{|l|}{ Birgitic: } \\
\hline Birgit & Píríndídìy-á & Pìrindiidèy \\
\hline Toram & irindeed-à & irinded \\
\hline \multicolumn{3}{|l|}{ Danglaic: } \\
\hline Dangaleat & érîndíl-غ̀ & ćríndíl-nà \\
\hline Bidiya & Pìrindiy-o & Pirínday \\
\hline Migama & Pírindè & Pìrind-ingée \\
\hline \multicolumn{3}{|l|}{ Southern Guera: } \\
\hline Barayin (Lovestrand 2021) & ríndi & ríndí-yá \\
\hline
\end{tabular}




\section{The role of Arabic in the development of $B u C o o D u F$}

Having established in section 3 that Mubic shows a phonologically irregular reflex $B u C o o D u F(e) /$ $B i C e e D i F<{ }^{*} B v C a a D v F-u / i$ of the East Chadic plural pattern ${ }^{*} B v C D a a F$, and in section 4 that the Mubi speech community is sufficiently familiar with the Arabic plural pattern $\operatorname{BaCaaDi}(i) F(e)$ not only to maintain it for borrowed nouns but to extend it to inherited ones, we are now in a position to understand the role of contact in the development of Mubic quadriliteral plurals BuCooDuF / BiCeeDiF.

In section 5.1, it is demonstrated that Arabic $B a C a a D i(i) F$ plurals are sometimes adapted to inherited $B u C o o D u F$, suggesting that bilingual speakers previously identified the former as corresponding to the latter. Such cross-linguistic identifications of Mubi plural patterns with Arabic ones would have encouraged convergence of the two. Closer examination of the inter-paradigmatic relationships of quadriliteral internal plurals within a given language reveals a single key point of convergence: template mapping directionality. In Arabic and Mubi the stem is mapped to the pattern from left-to-right, as shown in section 5.2, whereas in Northern Guera and indeed other Chadic languages the mapping is right-to-left, as demonstrated in section 5.3. This makes it possible to understand the Mubic plural as reflecting Arabic influence on a pre-existing inherited Chadic plural, rather than as straightforward replacement.

\subsection{Arabic loanwords into Mubi}

As shown in section 4 above, Arabic quadriliteral nouns borrowed into Mubi rather frequently retain their original plural $\mathrm{BaCaaDi}(i) F$, without so much as height spreading. Arabic speakers have been present in the region for nearly a millennium, so it appears likely that Mubi speakers were already borrowing Arabic nouns before adopting this pattern directly. The few available examples suggest that, at that stage, they treated $B u C o o D u F$ as the Mubi equivalent of Arabic BaCaaDi(i)F.

The clearest case (morphologically complex in Chadian Arabic) is:

(24) (à)ngúmbùl "calabash" > (à)ngùnóobùl (Chadian am-gumbul > am-ganaabil; am- 'mother' is a frequent compound formative; gumbul must, like Modern Standard Arabic qunbulah 'bomb', derive via Ottoman Turkish kumbara from Persian xumbâre 'small jar' (Procházka 2009). The assimilation of the $m$ seen in the Mubi form can also occur within Chadian Arabic when the morpheme $a m$ - is followed by a velar (Zeltner \& Tourneux 1986: 51-52).

The following case is also promising. Phonologically one might have expected *kòrkúr, but the attested tone and vowels can perhaps be explained as replacing partial with full reduplication. The semantics are acceptable, since bees often construct hives inside holes in trees:

kórkór(o) 'hive' > kúróokúr (cf. Chadian karkuur 'hole (e.g. in tree)'> karaakiir, Classical Arabic karkuur 'deep valley')

More problematic connections can be suggested for a couple more, but neither has clear cognates outside of Chad, so the direction of borrowing would in any case be unclear:

fórfórō 'honeycomb' > fùróofúr (cf. Chadian farfar 'awning, trellis' > faraafir?)

múlmúl-i 'calf (of leg)'> múlóomúl (cf. Chadian balbuut 'calf' > balaabiit?) 
The two first examples, however, are sufficient to establish that some Arabic quadriliteral nouns taking $B a C a a D i(i) F$ have been borrowed with this plural mapped to $B u C o o D u F$. The $o$ of 'hive' (rather than $a$ ) suggests that such forms represent an earlier stratum of Arabic borrowings, before rounding spread stopped getting applied to new loanwords.

\subsection{LTR mapping: shared between Arabic and Mubi}

If we compare the plurals of words of different lengths, it becomes possible to identify a more abstract trait that Arabic and Mubic share, not found in other Chadic languages examined. Within Arabic, comparison between the quadriliteral iambic plural and similar triliteral plurals indicates that the long vowel marking the plural is positioned relative to the beginning of the word, always appearing after the onset of the second mora: maktuub 'letter' $>$ [makaa] tiib like kalb 'dog' > $[$ kilaa $]$ b. This fact, applicable to most Arabic broken plural patterns, is what motivates the label 'iambic', describing the prosodic structure of the first two syllables of the plural (McCarthy \& Prince 1990). The mapping of the consonants of the singular to the plural pattern likewise proceeds from left to right, as confirmed by the occasional cases where this pattern is applied to words of more than four consonants, resulting (setting aside sonority effects) in the dropping of the last consonant: Sandaliib 'nightingale' > Sanaadil, jaћmariš 'old woman' > jaћaamir.

In Mubi, an analysis in terms of left-to-right mapping is likewise confirmed by comparison with triliterals, which typically take a template $B u \operatorname{CooD}(u)$ : kórkór(o) 'hive' > [kúróo]kúr like càrgò 'sisal' > [ciròo]gú, kàságàr 'sword' > [kùsóo]gúr like támák 'sheep' > [túmóo]k. For more examples of this template, see also:

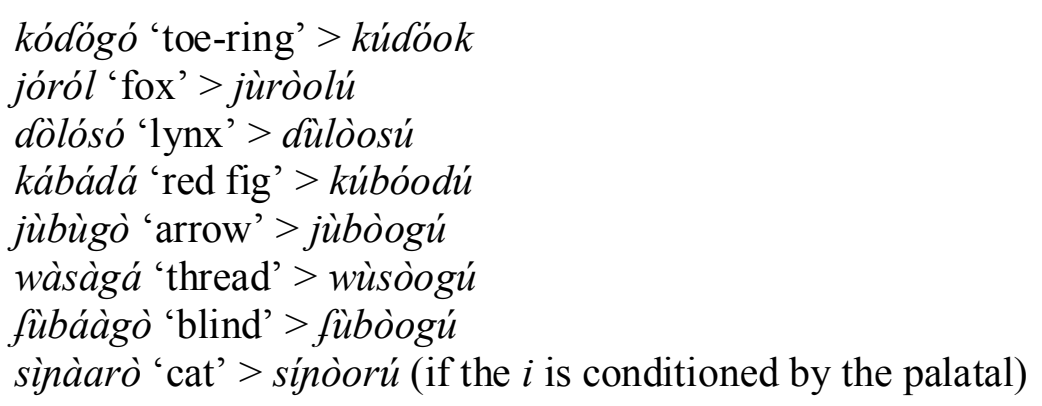

While occasionally attested, $B o o C u D$ triliteral plurals have a much more restricted distribution in Mubi, occurring only when the second mora is part of a long vowel (káarúmo 'fingernail' > kóorúm) or diphthong (néygó 'orphan' > nòoyùk).

Occasionally, triliteral singulars form plurals using the quadriliteral $B u C o o D u F$ pattern. In such cases, $B, C$, and $D$ always reflect the first three consonants respectively of the singular, while $F$ is filled out either with a $k$ not found in the singular, e.g.:

cágádá 'hut' > cúgóodúk

úrdé 'granary' > úróodúk

or by a copy of $D$ :

bòdòl "road" > bùdòolúl

kòròojó "small calabash" > kòròojúc (with exceptional maintenance of $o$ in the first syllable)

This further confirms that Mubi iambic plurals involve left-to-right mapping. 


\subsection{RTL mapping: reconstructible for Northern Guera}

In contrast with Mubic and indeed Arabic, Northern Guera languages display a rather different situation, as seen in Table 4. There, comparison with triliterals indicates that the position of the - $a$ is determined by right-to-left mapping, with the - $a$-always placed before the onset of the last mora: Mogum mirtél-é 'donkey' > mírtal like toyr-o 'eyebrow' > tojar; Dangaleat dürkùl 'donkey' > dúrkál like lòkùm-ò > lókkám (cf. Newman 1990: 40). Comparisons with quinqueliterals leads to the same conclusion, as illustrated in Table 4 by 'pebble': whatever the length of the singular, the $a$ always appears in the final syllable of this plural type.

To reconstruct the corresponding triliteral plural type, it is also necessary to note the fate of the middle consonant. The gemination witnessed in Dangaleat is also found in Migama plurals with high vowel lowering, and seems to be reflected by fortition in Mogum logóm 'camel' > lokám; it is consistently absent only when the first syllable has a long vowel, as in two of the last three examples in Table 4. The corresponding proto-Northern Guera triliteral plural should thus be reconstructed as geminating $C$ when necessary in order to ensure an output with two heavy syllables: sg. $* B V C V D(v)>*_{B} V C C a(a) D,{ }^{*} B V V C V D(v)>*_{B} V V C a(a) D$ (in this case, no available evidence supports the length of $a$, but this may simply result from closed-syllable shortening, since for triliterals no cases with an additional suffix $-e$ happen to be available).

Table 4. Triliteral a-plurals across East Chadic B

\begin{tabular}{|c|c|c|c|c|c|c|c|}
\hline & Kajakse & Mubi & Migama & Dangaleat & Bidiya & Mogum & Toram \\
\hline camel & - & $\begin{array}{l}\text { lògòmò } \\
\text { lògòm }\end{array}$ & $\begin{array}{l}\text { lókùmù } \\
\text { lòkkòmmì }\end{array}$ & $\begin{array}{l}\text { lòkùmò } \\
\text { lókkám }\end{array}$ & $\begin{array}{l}\text { lókmò } \\
\text { lókmè }\end{array}$ & $\begin{array}{l}\text { logóm } \\
\text { lokám }\end{array}$ & lòkòm \\
\hline buffalo & - & kibéeni & $\begin{array}{l}\text { kòpinú } \\
\text { kòpinò }\end{array}$ & kúpínò & $\begin{array}{l}\text { kopino } \\
\text { kopónpine }\end{array}$ & $\begin{array}{l}\text { káfiné } \\
\text { káfan }\end{array}$ & - \\
\hline $\begin{array}{l}\text { termite } \\
\text { mound }\end{array}$ & tuggu & $\begin{array}{l}\text { tùbùgí } \\
\text { tùbàayàk }\end{array}$ & - & $\begin{array}{l}\text { túpùr(ù) } \\
\text { túppár }\end{array}$ & tumpúlkò & - & - \\
\hline hearth & - & - & - & $\begin{array}{l}\text { tûkìnà } \\
\text { túkkán }\end{array}$ & $\begin{array}{l}\text { tokínà } \\
\text { tòkónkine }\end{array}$ & - & - \\
\hline bamboo & - & - & $\begin{array}{l}\text { tòròm } \\
\text { tórròmmi }\end{array}$ & $\begin{array}{l}\text { tòròm } \\
\text { tórrám }\end{array}$ & $\begin{array}{l}\text { torma } \\
\text { toròy }\end{array}$ & - & - \\
\hline $\begin{array}{l}\text { Guenon } \\
\text { monkey }\end{array}$ & - & - & - & $\begin{array}{l}\text { gùdìnà } \\
\text { gúddán }\end{array}$ & $\begin{array}{l}\text { gùdìnà } \\
\text { gúdán }\end{array}$ & - & - \\
\hline twin & - & máanò & $\begin{array}{l}\text { máàjibú } \\
\text { màajibi }\end{array}$ & $\begin{array}{l}\text { móòsìnè } \\
\text { móòsàn }\end{array}$ & $\begin{array}{l}\text { mòosínò } \\
\text { mòosínè }\end{array}$ & - & - \\
\hline big axe & - & - & - & & - & $\begin{array}{l}\text { dóokúmó } \\
\text { dookam }\end{array}$ & - \\
\hline pebble & - & kéréngèl & - & $\begin{array}{l}\text { bárìngilò } \\
\text { bárìygál }\end{array}$ & $\begin{array}{l}\text { biringílò } \\
\text { biringal }\end{array}$ & - & - \\
\hline
\end{tabular}

While an exhaustive survey across Chadic will not be attempted here, West Chadic languages examined also use right-to-left mapping for internal plurals. In Hausa, changes in internal vowel structure marking pluralization always affect the penultimate and final vowels, never the initial vowel (Hellwig \& McIntyre 2000: 5; citing Wolff 1993). In Bade, just as in Northern Guera, comparison of non-reduplicative internal- $a$ plurals of different lengths shows that the $a$ replaces the vowel of the last syllable of the singular stem, leaving internal consonant clusters intact: compare triliteral kùt̀̀r-aan 'puppy' > kùtàaro- $n$ with quadriliteral kudgùm-ən 'widow' > kudgwàamo-n (Schuh 2002: 16). This further suggests that Northern Guera is conservative in this respect. 
In section 3.4, it was shown that Mubi seems to retain relics of a similar plural formation, allowing this plural type to be reconstructed for proto-East Chadic B. In light of the discussion in this section, the change in proto-Mubic from *BvCDaaF-u to ${ }^{*} B v C a a D v F-u$ can now be understood as reflecting a directionality shift in this plural type, ultimately copied from Arabic.

\section{Conclusion}

From the data examined above, it appears:

1. that the position of the $a a$ in the proto-East Chadic B quadriliteral internal plural $* B V C D a a F$ shifted irregularly to $* B v C a a D v F$ in proto-Mubic to yield (with a suffix $-u$, later lost) modern Mubi BuCooDuF;

2. that this results from a directionality shift, changing Mubic to left-to-right template application (like that of Arabic);

3. that the two most frequent quadriliteral plural types in Mubi are irregularly inherited $B u C o o D u F(e)$ and Arabic BaCaaDi(i)F(e);

4. that at least one, and perhaps up to four, Arabic loanwords have shifted from a $\mathrm{BaCaaDi}(\mathrm{i}) \mathrm{F}$ plural to a $B u C o o D u F$ plural, confirming the perceptual similarity between the two;

5. and that, presumably more recently, at least one inherited Chadic word has shifted to an Arabic $\mathrm{BaCa} \mathrm{CiFe}$ plural, confirming the latter's productivity within Mubi.

In light of all this, a contact explanation for the irregular shift of *BVCDaaF to *BvCaaDvF in proto-Mubic appears unavoidable - but an explanation in terms of straightforward pattern borrowing alone, as with Tigre BaCaaDiF plurals from Arabic (Bulakh \& Kogan 2011), would not adequately explain the lexical distribution. The influx of Arabic loanwords retaining their plurals made it necessary for speakers to be able to apply templates from left to right. The similarity between Arabic and Mubi triliteral templates with long *aa, alongside the borrowed Arabic quadriliteral template, provided an easy point of departure for restructuring Mubic quadriliteral plurals along Arabic lines by setting the position of the *aa relative to the left edge instead of the right. To use the terminology of Matras and Sakel (2007), the shared presence of internal aa in both Arabic and Mubi plurals allowed the difference in directionality to be interpreted as the pivotal feature of the Arabic quadriliteral iambic plural, and thus to be copied from Arabic into the inherited East Chadic quadriliteral internal- $a$ plural. Modern Mubi $B u C o o D u F$ is thus a genetically hybrid morpheme, inheriting its lexical distribution in large part from inherited quadriliteral ${ }^{*} B V C D a a F$, and taking its vowel quality primarily from the pre-Mubi plural suffix $-u$ and the inherited triliteral pattern $B u C o o D u$, but borrowing its shape from Arabic BaCaaDiF. This scenario is reminiscent in some respects of what Arkadiev (2021) describes for Kabardian-Abaza contact, where the position of an inherited morpheme is changed to better match that of its functional counterpart in the influencing language.

In the less probable event that the inadequately supported reduplicative plural *BVCaaBVC can be reconstructed for proto-Chadic (see discussion in section 3.4), the history of Mubi $\mathrm{BuCooDuF}$ would be slightly different: the influx of Arabic loans taking iambic plurals, and their similarity to the more restricted reduplicative plural that was already present, would have provided the motivation for generalizing the latter to the non-reduplicated quadriliterals (yielding ${ }^{*} B V C a a D V F$ ), replacing *BVCDaaF entirely. The latter scenario would perfectly parallel the findings of Cruschina (2021) for Italian-Sicilian contact: there, as here, we see that when a productive plural marker in one language is identical in form to a plural marker in another, contact can increase its productivity in the latter by causing it to be generalized to nouns that formerly took a non-shared plural marker. 
In either scenario, the etymology of this plural pattern simultaneously reflects Chadic inheritance and Arabic influence, in a manner reminiscent of Zuckermann's (2004) 'phono-semantic matching' but involving morphology rather than lexemes. This unexpected outcome provides further support for the hypothesis that root-and-pattern morphology spreads much more easily between even distantly related languages than between unrelated ones (Souag 2020): not only can patterns more easily be borrowed in such circumstances, as illustrated for Mubi above by the case of 'scorpion', they can also recombine to produce hybrid patterns of dual origins.

\section{Acknowledgements}

I thank the editors and anonymous reviewers for their useful comments on this manuscript, and Joseph Lovestrand for helping track down some otherwise inaccessible sources. 


\section{References}

Alio, Khalil. 2004. Préliminaires à une étude de la langue kajakse d'Am-Dam, de toram du Salamat, d'ubi du Guéra et de masmaje du Batha-Est (Tchad). In Takács, Gábor (ed.), Egyptian and Semito-Hamitic (Afro-Asiatic) studies: In memoriam W. Vycichl, 229-285. Leiden: Brill.

Alio, Khalil. 2008. Conflict, mobility and language: The case of migrant Hadjaraye of Guéra to neighboring regions of Chari-Baguirmi and Salamat (Chad). ASC Working Paper 82. 1-23.

Alio, Khalil \& Hermann Jungraithmayr. 1989. Lexique bidiya: une langue centre-africaine (République du Tchad) avec une introduction grammaticale. Frankfurt am Main: Klostermann.

Arcodia, Giorgio Francesco. 2013. Nonconcatenative morphology in typological perspective. In Arcodia, Giorgio Francesco \& Da Milano, Federica \& Iannàccaro, Gabriele \& Zubena, Paolo (eds.), Tilelli: Studi in onore di Vermondo Brugnatelli, 1-14. Roma: Caissa Italia.

Arkadiev, Peter. 2021. Borrowing non-canonical inverse between Kabardian and Abaza. Word Structure 14(2). XXX-XXX.

Arnold, Werner. 2007. Arabic grammatical borrowing in Western Neo-Aramaic. In Matras, Yaron \& Sakel, Jeanette (eds.), Grammatical borrowing in cross-linguistic perspective, 151-164. Berlin: De Gruyter.

Baldi, Sergio \& Jungraithmayr, Hermann. 2008. Mots d' origine arabe en mubi (Tchad). Zeitschrift der Deutschen Morgenländischen Gesellschaft 158(1). 25-37.

Bargery, George P. 1934. A Hausa-English dictionary and English-Hausa vocabulary. London: Oxford University Press.

Bulakh, Maria \& Kogan, Leonid. 2011. Arabic influences on Tigre: A preliminary evaluation. Bulletin of the School of Oriental and African Studies, University of London 74(1). 1-39.

Bye, Patrik \& Svenonius, Peter. 2012. Non-concatenative morphology as epiphenomenon. In Trommer, Jochen (ed.), The morphology and phonology of exponence. Oxford: Oxford University Press.

Caprile, Jean-Pierre. 1975. Lexique tumak-français (Marburger Studien zur Afrika- und Asienkunde 5). Berlin: Reimer.

Coghill, Eleanor. 2015. Borrowing of verbal derivational morphology between Semitic languages: The case of Arabic verb derivations in Neo-Aramaic. In Borrowed morphology. Berlin: De Gruyter. https://doi.org/10.1515/9781614513209.83.

Cruschina, Silvio. 2021. Language contact and morphemes in competition: Plurals in central Sicily. Word Structure 14(2). XXX-XXX.

Fédry, Jacques. 1971. Dictionnaire dangaléat (Tchad). Lyon: Afrique et Langage.

Frajzyngier, Zygmunt. 1981. Some rules concerning vowels in Chadic. Bulletin of the School of Oriental and African Studies 44(2). 334-348.

Gardani, Francesco. 2020. Morphology and contact-induced language change. In Grant, Anthony (ed.), The Oxford handbook of language contact, 96-122. Oxford: Oxford University Press.

Greenberg, Joseph H. 1963. The languages of Africa. Bloomington: Indiana University.

Hammarström, Harald \& Forkel, Robert \& Haspelmath, Martin. 2019. Glottolog 4.1. Max Planck Institute for the Science of Human History. http://glottolog.org (20 March, 2020).

Harris, Zellig S. 1942. Morpheme alternants in linguistic analysis. Language 18(3). 169-180.

Hellwig, Birgit \& McIntyre, Joseph A.. 2000. Hausa plural systems: A diachronic presentation. Journal of African Languages and Linguistics 21. 1-43.

Hockett, Charles F. 1954. Two models of grammatical description. Word 10(2). 210-234.

Jaggar, Philip J. 2001. Hausa (London Oriental and African Language Library 7). Amsterdam: Benjamins.

Johnson, Eric C. 2005. Étude sociolinguistique de la langue Zirenkel du Tchad. SIL Electronic Survey Reports 2005-023. 1-30.

Johnson, Eric C. \& Mbernodji, Calvain. 2006. Enquête sociolinguistique de la langue Moubi du Tchad. SIL Electronic Survey Reports. 
Jullien de Pommerol, Patrice. 1999. Dictionnaire arabe tchadien-français: suivi d'un index français-arabe et d'un index des racines arabes. Paris: Karthala.

Jungraithmayr, Hermann. 1961. Beobachtungen zur tschadohamitischen Sprache der Jegu (und Jonkor) von Abu Telfan (République du Tchad). Afrika und Übersee 45. 95-123.

Jungraithmayr, Hermann. 1978. Gebrochene Plurale im Mubi (Ost-Tschad). In Jungraithmayr, Hermann (ed.), Struktur und Wandel afrikanischer Sprachen, 121-131. Berlin: Reimer.

Jungraithmayr, Hermann. 2004. Das Birgit, eine Osttschadische Sprache - Vokabular und grammatische Notizen. In Takács, Gábor (ed.), Egyptian and Semito-Hamitic (Afro-Asiatic) studies in memoriam W. Vycichl. Leiden: Brill.

Jungraithmayr, Hermann. 2013. La langue mubi (République du Tchad). Précis de grammaire. Textes. Lexique. Berlin: Reimer.

Jungraithmayr, Hermann. 2018. From Mubi to Ngas-A History of Evolution in Chadic. Zeitschrift der Deutschen Morgenländischen Gesellschaft 168(1). 1-14.

Jungraithmayr, Hermann \& Adams, Abakar. 1992. Lexique migama: migama-français et françaismigama (Guéra, Tchad) avec une introduction grammaticale. Berlin: Reimer.

Koch, Harold. 2015. Morphological reconstruction. In Bowern, Claire \& Evans, Bethwyn (eds.), The Routledge handbook of historical linguistics, 286-307. London: Routledge.

Kossmann, Maarten. 2010. Parallel system borrowing: Parallel morphological systems due to the borrowing of paradigms. Diachronica 27(3). 459-487. https://doi.org/10.1075/dia.27.3.03kos.

Lovestrand, Joseph. 2012a. Classification and description of the Chadic languages of the Guéra (East Chadic B). SIL Electronic Working Papers 2012(004).

Lovestrand, Joseph. 2012b. The linguistic structure of Baraïn (Chadic). Dallas: Graduate Institute of Applied Linguistics MA thesis.

Lovestrand, Joseph. 2021. Barayin lexicon [Data set]. Zenodo. http://doi.org/10.5281/zenodo.4610523.

Marti, Marianne \& Mbernodji, Calvain \& Wolf, Katharina. 2007. L'enquête sociolinguistique des langues birguit - kadjakse - masmedje du Tchad. SIL Electronic Survey Reports 2007-018. $1-56$.

Matras, Yaron. 2009. Language contact (Cambridge Textbooks in Linguistics). Cambridge, UK: Cambridge University Press.

Matras, Yaron \& Sakel, Jeanette. 2007. Investigating the mechanisms of pattern replication in language contact. Studies in Language 31(4). 829-865.

McCarthy, John J. \& Prince, Alan. 1990. Foot and word in prosodic morphology: The Arabic broken plural. Natural Language and Linguistic Theory 8. 209-282.

Newman, Paul. 1970. Historical sound laws in Hausa and in Dera (Kanakuru). Journal of West African Languages 7. 39-51.

Newman, Paul. 1977. Chadic classification and reconstructions. Afroasiatic Linguistics 5(1). 1-42.

Newman, Paul. 1990. Nominal and verbal plurality in Chadic. Dordrecht: Foris.

Newman, Paul. 2007. A Hausa-English dictionary. New Haven, CT: Yale University Press.

Owens, Jonathan \& Hassan, Jidda. 2008. West Sudanic Arabic. (Ed.) Versteegh, Cornelis H. M. (ed.), Encyclopedia of Arabic language and linguistics, 708-718. Leiden: Brill.

Peust, Carsten. 2018. The subgrouping of East Chadic. Folia Orientalia 55. 235-253. https://doi.org/10.24425/for.2018.124686.

Prickett, Davis. 2012. The phonology and morphology of verb forms in Mubi. Grand Forks: University of North Dakota MA thesis.

Procházka, Stephan. 2009. Turkish loanwords into Arabic. Versteegh, Cornelis H. M. (ed.), Encyclopedia of Arabic language and linguistics. Leiden: Brill.

Putten, Marijn van. 2020. Classical and Modern Standard Arabic. In Lucas, Christopher \& Manfredi, Stefano (eds.), Arabic and contact-induced change (Contact and Multilingualism), 57-82. Berlin: Language Science Press. 
Ratcliffe, Robert R. 1998. The 'broken' plural problem in Arabic and comparative Semitic: Allomorphy and analogy in non-concatenative morphology. Amsterdam: Benjamins.

Rendinger, Général de. 1949. Contribution à l'étude des langues nègres du Centre-africain. Journal des Africanistes 19(2). 143-194.

Roth-Laly, Arlette. 1969. Lexique des parlers arabes tchado-soudanais. / An Arabic-English-French lexicon of the dialects spoken in the Chad-Sudan area. Vol. 1-4. Paris: Editions du Centre national de la recherche scientifique.

Schuh, Russell. 2002. The nominal and verbal morphology of Western Bade. In Kaye, Alan S. (ed.), Morphologies of Africa and Asia. Winona Lake, IN: Eisenbrauns.

Souag, Lameen. 2002. Broken plurals - or infixes?: The Case of the Algerian Arabic of Dellys. Estudios de dialectología norteafricana y andalusi 6. 19-34.

Souag, Lameen. 2020. When is templatic morphology borrowed? On the spread of the Arabic elative. Morphology 30(4). 469-500. https://doi.org/10.1007/s11525-020-09360-8.

Souleyman, Abakar \& Abakar, Hisseine \& Ramat, Sakine. 2012. Découvrons le zerenkel: grammaire et discours. Unpublished ms.

Swadesh, Morris. 1934. The phonemic principle. Language 10(2). 117-129.

Vanhove, Martine. 2012. Roots and patterns in Beja (Cushitic): The issue of language contact with Arabic. In Stolz, Thomas \& Vanhove, Martine \& Otsuka, Hitomi \& Urdze, Aina (eds.), Morphologies in contact, 323-338. Berlin: Akademie Verlag.

Vanhove, Martine. 2020. Beja. In Lucas, Christopher \& Manfredi, Stefano (eds.), Arabic and contact-induced change, 419-439. Berlin: Language Science Press.

Wolff, H. Ekkehard. 1988. 'Ablaut' and accent in Chadic. In Brauner, Siegmund \& Wolff, H. Ekkehard (eds.), Progressive traditions in African and Oriental studies, 165-179. Berlin: Akademie Verlag.

Wolff, H. Ekkehard. 1993. Referenzgrammatik des Hausa: Zur Begleitung des Fremdsprachenunterrichts und zur Einführung in das Selbststudium. Münster: LIT.

Zeltner, Jean-Claude \& Tourneux, Henry. 1986. L'arabe dans le bassin du Tchad: le parler des Ulâd Eli. Paris: Karthala.

Zuckermann, Ghil'ad. 2004. Cultural hybridity: Multisourced neologization in 'reinvented' languages and in languages with 'phono-logographic' script. Languages in Contrast 4(2). 281-318. 